\title{
Study on the Effect of the Cultural View of Marx's Doctrine on the Education of University Culture
}

\author{
Hongxia Sun \\ Qilu Normal University (China Shandong250000)
}

\begin{abstract}
Keywords: Marx doctrine; Cultural view; University education; Culture education
\end{abstract}
\begin{abstract}
As an important force in the socialist culture with Chinese characteristics, university culture is responsible for the important historical mission of cultivating excellent talents for our country. This paper puts forward some thoughts on the cultural view of Marx in the culture of University, and aims at fully excavating the educational thought in Marx's cultural view, and providing the correct value guidance for the training of university talents.

As an important part of our educational system, university education has a unique campus culture. As the talent force of social development, college students are of great practical significance to the training of them. In order to cultivate excellent socialist successors with Chinese characteristics, we must always adhere to the guidance of Marx doctrine. General Secretary Xi once stressed that colleges and universities should pay more attention to educating people and strengthen the creation of civilized campus. Based on this, colleges and universities should dig into the cultural view of Marx's doctrine and give full play to the utility of "educating people with culture".
\end{abstract}

\section{Part One the Specific Connotation of Cultural View of Marx's Provides Theoretical Support for University Culture Educating People}

The essence of cultural view is Marx Engels in the labor process, mining, which gives a more "culture" connotation, and with its application in ideology, Marx believes that a difference between man and animal is that the former has created the aesthetic culture, which also determines the development of the social progress and development cannot do without culture. The aesthetic culture of Marx's aesthetics has laid a theoretical source for college culture to cultivate the aesthetic ability of college students. Engels's understanding of spiritual production that is exactly the same as that of the current narrow sense. Spiritual production can satisfy people's spiritual needs to a great extent, and urge people to internalize it into their own. To examine the current process of university culture education of Marx's view of culture from the perspective of the school, teachers should be good at guiding students from the spirit of advancing, dig the inherent potential of students and promote the continuous forward, therefore, Marx's view of culture has provided theoretical support for the university cultural education.

\section{Part Two the Intrinsic Relationship between Cultural Outlook and University Culture Education Provides Value Orientation}

The essential connotation cultural view of Marx's provides a theoretical basis for university culture education. This indicates that there is a certain internal connection between Marx's cultural view and university culture education.

Conforming to the development of the market economy. Culture is the product of economic and political, but its counteraction and economy and politics, the three mutual influence, and jointly promote the development of society. As an important part of social culture, university culture must deal with the relationship between itself and the development of social market economy in the process of development. The ultimate goal of talent training in Colleges and universities is to train a number of high-quality successors for the society, while cultural view of Marx's reveals the value system of social development, so as to train college students' right values.

Promoting the overall development of people. Promoting the all-round development of people is the core of Marx's doctrine, which will also be the fundamental purpose of educating people in 
university culture. The current international competition is an important part of the cultural soft power competition, strengthening the construction of social culture has important influence on the realization of the great rejuvenation of the China dream, therefore, universities should give full play to its educational function to provide adequate nourishment for the mind of college students, the effective combination of intellectual and moral education to promote the healthy and comprehensive development college students.

Meeting the needs of the development of the times. Religious culture indicates that the existence of any religion has its necessity and rationality, which is a culture that meets the needs of the development of the times. The period of Westernization set off a new wave of cultural development, and reformers actively advocated a new culture, a main theme of enlightenment and science in Colleges and universities that started quickly, after the reform and opening up, the text of the modernization of education has injected fresh blood for the cultivation of talents, that gradually improved the quality and efficiency of their own talents. As the main base of personnel training, universities should meet the needs of the times in the course of their development, and combine their own development with the needs of the times, constantly nurturing new culture, so as to promote their sustainable development.

Ideology dominates. Materialist conception of history emphasizes the relationship between material and spirit in the development process. Marx's guiding ideology is an ideological field in China that has an important influence on the construction of material civilization and spiritual civilization in China. In the education process, we must always adhere to the dominant ideology that combined with the current development trend of the times and set up the big ideological and political work idea, starting from the students' ideology, strengthening the ideological and political education of the. Based on the perspective of cultural view of Marx's, colleges and universities should constantly innovate their own ideas and ways of propaganda, effectively integrate their ideas and behaviors and help them grow healthily under good ideology and establish correct values.

\section{Part Three Marx's View of Culture is a Direction for the Construction of University Culture}

\section{Values Guide the Construction of Spiritual Culture}

All along, spiritual culture is the core and soul of all cultures. The construction of university spirit and culture includes its ideals, beliefs, value goals and future development plans. The spirit of culture has a certain degree of permeability, the permeability from the perspective of college students to the ideological and spiritual side, edify sentiment which helps students sound personality; spiritual culture is inherited, the tradition and innovation, so as to promote its sustainable development. The construction of university spiritual culture directly affects the effectiveness of cultural education. Therefore, we must dig deeper into the spiritual connotation of Marx's cultural view, cultivate advanced socialist culture, and build the university campus into a platform for the spread of social civilization. The construction of spiritual culture in Colleges and universities should guide college students to set up a correct world outlook that on life and values, so as to promote the individualized development of college students.

\section{Innovating Spirit and Perfecting the Construction of Campus System Culture}

Students must be influenced by culture in the process of growth and development, while the influence of campus culture is bound by the system, the campus culture itself has self discipline content which comes from the systematic development of a certain culture system. The modern university system mainly includes management system, teaching system and behavior standard. These systems form a system culture in the process of execution, which has certain guiding, restricting and standardizing functions for the whole university campus culture. The campus culture system plays a certain role in standardizing school teaching and college students' behavior. Therefore, advanced system culture can provide a strong impetus for colleges and universities, and backward institutional culture will hinder the development of colleges and universities. The spirit of innovation is a kind of cultural spirit advocated by the society. On this basis, the campus culture system should follow the development of the times to achieve self renovation and self-improvement, so as to enhance the construction of campus culture system. 


\section{Setting up Environmental Culture with Special Education}

The environment culture of university campus is a unique cultural form of university, it is the bridge and link of university culture education, and has certain special educational function. Environmental culture is the basis and premise for the emergence and development of other campus culture. It reflects the unique historical tradition, cultural style and spiritual pursuit of our school. Environmental culture is important because it has a rich cultural connotation, and the cultural connotation embodied in educational thoughts, teaching attitude, teaching facilities in Colleges and universities and pavilion and construction, in addition, the environment culture is also reflected in the way of campus culture spread, such as campus radio, campus website, bulletin board. Since ancient times, the infection ability of the environment to human being is very strong. It has edifying the sentiment of college students through environmental infection, imperceptibly and moistening things, and guides college students to improve themselves through good atmosphere.

\section{Vocational Service Cultivating College Behavior Culture}

The so-called behavior culture is the general name of behavior subject in university in the aspects of school teaching, scientific research, academic exchange, learning and life. It fully embodies the spirit and cultural taste of the main body of university behavior, and fully embodies the spirit of university culture. To cultivate behavior culture in Colleges and universities, we must first fully respect the "people-oriented" teaching concept, fully respect the dominant position of universities and give full play to the guiding role of teachers, and carry out a series of personnel training, scientific research and cultural exchange activities. As the two main bodies of university campus, school teachers and students directly participate in and influence the cultural construction of colleges and universities, and promote the construction of campus culture on the basis of fully mobilizing their subjective initiative. The teacher as the evergreen tree in the university campus, the professional qualities and values of students' comprehensive development plays an important role, which determines its important role in the construction of campus culture, in order to find the occupation to create teachers' own sense of pride and sense of belonging, and promote their own progress. Teachers should combine their professional ethics, give full play to their professional service functions, help students establish correct world outlook which lies on life and values in the process of imparting scientific and cultural knowledge, and cultivate behavior culture in universities.

\section{Conclusion}

The main body of university culture is school teachers and students. University teachers should give full play to their role as the leader of campus culture construction, actively carry forward the healthy and elegant campus culture, and create a good atmosphere for the self-development of college students. In a civilized campus, college students accept the edification of Marx's concept of culture in order to help themselves to set up lofty and correct ideals.

\section{Reference}

[1] Sheng Wei.The source of the theory of Marx's view of culture[J].People's Forum and Academic Frontiers,2017(12):92-95.

[2] Fang Zhang.Guiding the construction of college campus culture with the cultural view of Marx's[J].Industry and Science and Technology Forum,2017,16(17):180-181.

[3] Wenjuan Huang.Marx's view of culture and its contemporary value[J].Journal of Lanzhou Institute of Industry,2017,24(04):112-114.

[4] Yupei Liu.Study on the cultural construction of colleges and Universities under the view of Marx's culture[D].Dalian Maritime University,2013.

[5] Guirong Hao.Research on Cultural Education in Colleges and Universities[D].Liaoning University,2017.

[6] Shaoxia Wang.Investigation and analysis of college students' cultural outlook and cultural attainment[J].Research on Ideological Education,2015(11):60-64. 